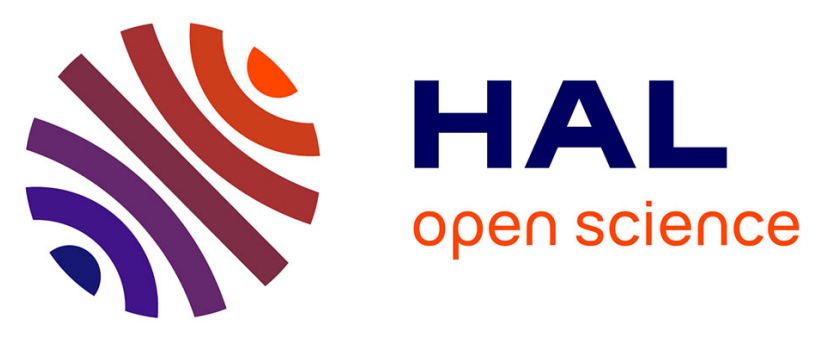

\title{
The pH-Induced Selectivity Between Cysteine or Histidine Coordinated Heme in an Artificial alpha-Helical Metalloprotein
}

Karl J Koebke, Toni Kühl, Elisabeth Lojou, Borries Demeler, Barbara Schoepp-Cothenet, Olga Iranzo, Vincent L Pecoraro, Anabella Ivancich

\section{To cite this version:}

Karl J Koebke, Toni Kühl, Elisabeth Lojou, Borries Demeler, Barbara Schoepp-Cothenet, et al.. The pH-Induced Selectivity Between Cysteine or Histidine Coordinated Heme in an Artificial alphaHelical Metalloprotein. Angewandte Chemie International Edition, 2021, 60 (8), pp.3974-3978. 10.1002/anie.202012673 . hal-03017501v3

\section{HAL Id: hal-03017501 \\ https://hal.science/hal-03017501v3}

Submitted on 18 Oct 2021

HAL is a multi-disciplinary open access archive for the deposit and dissemination of scientific research documents, whether they are published or not. The documents may come from teaching and research institutions in France or abroad, or from public or private research centers.
L'archive ouverte pluridisciplinaire HAL, est destinée au dépôt et à la diffusion de documents scientifiques de niveau recherche, publiés ou non, émanant des établissements d'enseignement et de recherche français ou étrangers, des laboratoires publics ou privés. 
How to cite: Angew. Chem. Int. Ed. 2021, 60, 3974-3978

\title{
The pH-Induced Selectivity Between Cysteine or Histidine Coordinated Heme in an Artificial $\alpha$-Helical Metalloprotein
}

\author{
Karl J. Koebke, Toni Kühl, Elisabeth Lojou, Borries Demeler, Barbara Schoepp-Cothenet, \\ Olga Iranzo, Vincent L. Pecoraro, * and Anabella Ivancich*
}

\begin{abstract}
De Novo metalloprotein design assesses the relationship between metal active site architecture and catalytic reactivity. Herein, we use an $\alpha$-helical scaffold to control the iron coordination geometry when a heme cofactor is allowed to bind to either histidine or cysteine ligands, within a single artificial protein. Consequently, we uncovered a reversible $\mathrm{pH}$ induced switch of the heme axial ligation within this simplified scaffold. Characterization of the specific heme coordination modes was done by using UV/Vis and Electron Paramagnetic Resonance spectroscopies. The penta- or hexa-coordinate thiolate heme $(9 \leq p H \leq 11)$ and the penta-coordinate imidazole heme $(6 \leq p H \leq 8.5)$ reproduces well the heme ligation in chloroperoxidases or cyt $P 450$ monooxygenases and peroxidases, respectively. The stability of heme coordination upon ferric/ferrous redox cycling is a crucial property of the construct. At basic pHs, the thiolate mini-heme protein can catalyze $\mathrm{O}_{2}$ reduction when adsorbed onto a pyrolytic graphite electrode.
\end{abstract}

$\boldsymbol{P}$ interrogate biomolecular function using well-defined changes to enzyme active site structure. De Novo protein design has emerged as a subfield allowing assessment of fundamental features controlling protein structure and function. ${ }^{[1,2]}$ In particular, De Novo metalloprotein design has provided detailed insight into the relationship between the architecture of metal active sites and electron transfer or catalytic reactions. ${ }^{[3]}$ In many cases, these synthetic systems utilize highly stable $\alpha$-helical scaffolds capable of binding a broad range of metals and metal cofactors (reviewed in ${ }^{[4]}$ ). Among

[*] Dr. K. J. Koebke, Prof. V. L. Pecoraro

Department of Chemistry, University of Michigan

Ann Arbor, MI 48109 (USA)

E-mail:vlpec@umich.edu

Dr. T. Kühl, Dr. E. Lojou, Dr. B. Schoepp-Cothenet, Dr. A. Ivancich Laboratoire de Bioénergétique et Ingénierie des Protéines (UMR 7281), IMM FR3479, CNRS, Aix-Marseille Univ.

Marseille (France)

E-mail: aivancich@imm.cnrs.fr

Dr. B. Demeler

Department of Chemistry and Biochemistry, University of Lethbridge Lethbridge, AB, T1K 3M4 (Canada)

Dr. O. Iranzo

Institut des Sciences Moléculaires de Marseille (iSm2), Centrale Marseille, Aix-Marseille Univ., CNRS

Marseille (France)

(2) Supporting information and the ORCID identification number(s) for the author(s) of this article can be found under: https://doi.org/10.1002/anie.202012673. the most important and ubiquitous natural metalloenzymes are those containing the iron porphyrin cofactor, known as heme. Heme-containing proteins are involved in fundamental biological processes such as oxidative metabolism, oxygen storage and transport, signal transduction and drug metabolism. ${ }^{[5]}$ The heme site is capable of catalyzing a variety of biologically-relevant chemical reactions, such as disproportionation of hydrogen peroxide (catalases ${ }^{[6]}$ ), oxidation and haloperoxidation of organic substrates (monofunctional heme peroxidases, ${ }^{[7]}$ bi-functional catalase-peroxidases ${ }^{[8]}$ ) and oxygenation reactions (cyt P450 monooxygenases (Figure S1) and nitric oxide synthase $\left.{ }^{[7]}\right)$. Such a functional versatility relies upon variations in the heme coordination (i.e. His, Tyr, Cys or Met axial ligand(s)), as well as being significantly modulated by the heme environment $\left(2^{\text {nd }}\right.$ coordination sphere and H-bond networks). Studies of heme active sites using mutational analysis, structural biology and molecular spectroscopy provide essential information on the natural systems that delimit the catalytic processes. Yet, the complexity of the natural systems often masks the specific behavior of the metal cofactor. For this reason, small artificial proteins capable of binding heme at specified sites are being developed. ${ }^{[9,10]}$ Our approach is to use $\alpha$-helical scaffolds to provide ligation to the heme as cofactor to explore heme axial ligand selectivity, specifically hoping to define how one can control the iron coordination geometry when a heme is afforded an opportunity to bind either histidine (imidazole) or cysteine (thiolate) ligands. While many studies of de novo designed scaffolds with heme binding to nitrogenous ligands have been reported (reviewed in [11]), there have been limited studies examining either synthetic thiolate-bound $\mathrm{Fe}^{\mathrm{III}}$-porphyrin complexes ([12] and references therein) or His-to-Cys mutations in natural heme enzymes ${ }^{[13,14]}$ as structural models for the cytP450 monooxygenases and chloroperoxidases (CPO) thiolate axial ligands. The putative heme preference between such ligands has not been addressed within a single artificial protein. In this communication, we assess the preference of heme binding to selfassembling $\alpha$-helical coiled coils as a function of $\mathrm{pH}$. We uncover a remarkable $\mathrm{pH}$-driven conversion of the heme ligation, between the 5-coordinated (5-c) histidine structures (peroxidase-like) at neutral $\mathrm{pH}$ to thiolate bound structures that are 5-c at $\mathrm{pH} \geq 9$ or 6-coordinated (6-c) at $\mathrm{pH} 10$. In addition to providing rare examples of water-stable heme thiolate models, this work illustrates the ability to exploit proton concentration to switch heme coordination preferences in a protein through the simple expedient of $\mathrm{pH}$. Thus, along with providing fundamental insight into metalloprotein structural preferences, our studies potentially allow for the 
$\mathrm{pH}$-induced conversion from peroxidase-like catalytic activity (imidazole) to oxygenase (thiolate) reactivity.

The GRAND peptide family has been studied extensively for transition metal and heavy metalloid binding. ${ }^{[15]}$ In the apo form, they generate highly stable three stranded coiled coils (3SCCs) at $\mathrm{pH} \geq 5$, or two stranded coiled coils (2SCCs) at more acidic $\mathrm{pHs}$, illustrating the structural versatility in this system. ${ }^{[16]}$ Furthermore, 2SCCs with oppositely charged residues at e and $\mathrm{g}$ heptade positions can associate to form antiparallel 4SCCs. ${ }^{[17]}$ The coiled coils are stabilized through hydrophobic interactions (typically leucines) embedded at a and d positions of repeating heptads. These sites can be modified to include metal binding residues, such as cysteine or histidine, to incorporate a stabilizing metal within the hydrophobic interior ${ }^{[18]}$ Table 1 shows the specific peptide sequences used in this work. Each leucine mutation leads to a small destabilization of the system, although two or three changes are well tolerated. ${ }^{[19,20]}$

All the GRAND peptides (Table 1) showed CD spectra typical of well-folded coiled-coils across a wide $\mathrm{pH}$ range, both with and without heme (Figure S2 and Figure S3A).
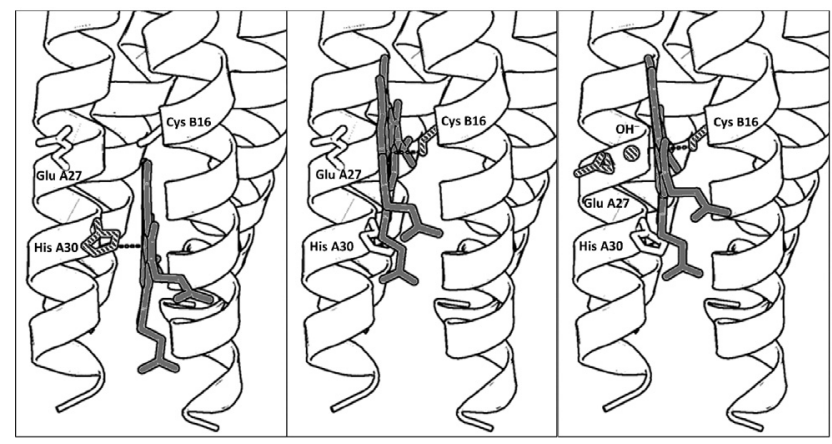

Figure 1. PyMol models illustrating the proposed folding of GRWL16CL30H peptides complexed with heme (a dimer of antiparallel $2 \mathrm{SCC}$ ) at selected $\mathrm{pH}$ values. The three coordination configurations concluded from our spectroscopic study, that is, His-pentacoordinated heme ( $\mathrm{pH} 7$, left panel), Cys-pentacoordinated heme ( $\mathrm{pH} 9.0$, center panel) and Cys/hydroxide hexacoordinated heme ( $\mathrm{pH} 10.5$, right panel) are shown. Only the heme for one antiparallel 2SCC (A and B $\alpha$ helices) is shown for clarity. The PyMol models are based on the crystal structure of a de novo designed antiparallel 4SCC (PDB code: 2B1F) as described in Supplementary Information. A color version of the models is shown in Figure S5.
Table 1: Sequences of the GRAND peptides used in this study.

\begin{tabular}{|c|c|c|c|c|c|c|c|}
\hline Peptide & 1 & 2 & 9 & 16 & 23 & 30 & 37 \\
\hline GRAND L2W $(G R W)^{[a]}$ & $A_{C}-G$ & WKALEEK & LKALEEK & LKALEEK & LKALEEK & LKALEEK & $\mathrm{G}-\mathrm{NH}_{2}$ \\
\hline GRW-L16CL30H & $A C-G$ & WKALEEK & LKALEEK & CKALEEK & LKALEEK & HKALEEK & $\mathrm{G}-\mathrm{NH}_{2}$ \\
\hline GRW-L16C & $A C-G$ & WKALEEK & LKALEEK & CKALEEK & LKALEEK & LKALEEK & $\mathrm{G}-\mathrm{HN}_{2}$ \\
\hline GRW-L30H & $A_{C}-G$ & WKALEEK & LKALEEK & LKALEEK & LKALEEK & HKALEEK & $\mathrm{G}-\mathrm{NH}_{2}$ \\
\hline
\end{tabular}

[a] Peptides are amidated and acetylated at the $\mathrm{C}$ - and $\mathrm{N}$-terminus, respectively. The first residue of each heptad is labeled with its overall position within the peptide. Heme binding residues are in bold. excess, the increasing spectral contribution of hemin in buffer solution was observed (Figure 2 Inset, dashed trace).

We combined UV/Vis and Electron Paramagnetic Resonance (EPR) spectroscopies to characterize the specific coordination mode of the heme to the GRWL16CL30H peptide dimer in the

Also, once complexed with heme, peptides were thermodynamically more stable with $\mathrm{T}_{\mathrm{M}}$ increasing by $10^{\circ} \mathrm{C}$ at basic $\mathrm{pHs}$ (Figure S3B). Analytical Ultracentrifugation (AUC) studies confirmed that the apo peptides fold as 3SCCs (Figure S4A); however, the estimated molecular mass indicated formation of tetramers upon heme complexation (Figure S4B and S4C). We believe that the resulting GRAND mini-heme proteins are best described as dimers of antiparallel 2SCCs. Consequently, heme complexation to the 3SCCs apo GRAND peptides induces the conversion to 4SCCs, with a heme at the helical interface of each antiparallel dimer (Figure 1 and Figure S5). Conversion of a parallel 3SCC to an antiparallel 4SCC is not without precedent. ${ }^{[17]} \mathrm{A}$ recent report showed that two mutations in a model coiled coil peptide (HA2-DEL) were sufficient to convert the parallel 3SCC construct to an antiparallel 4SCC ${ }^{[21]}$

The heme to peptide stoichiometry for the mini-heme protein was assessed by monitoring the UV/Vis spectral changes of the heme. The absorption spectrum of hemin upon complexation with the GR2W-L16CL30H scaffold at pH 10.5 (Figure 2 Inset, solid traces), a low-spin thiolate heme (see Figure $3 \mathrm{~A}$ ), is clearly distinct to that of the hemin in buffer solution (Figure 2 Inset, dashed traces). Hemin titration into the GRW-L16CL30H peptide showed the complexation of one heme per peptide dimer (Figure 2). For higher hemin
$\mathrm{pH}$ range 6 to 11. Two clearly distinct absorption and EPR spectra (Figure $3 \mathrm{~A}$ and $\mathrm{B}$ ) were obtained for neutral (olive green traces) and basic (red traces) $\mathrm{pH}$ values. The absorption spectrum at $\mathrm{pH} 7.14$ (Figure $3 \mathrm{~A}$, olive green trace) is characteristic of a 5-c heme, with a ligand-to-metal charge transfer (LMCT) band at $640 \mathrm{~nm}$, reminiscent of peroxidases. $^{[7]}$ The corresponding axial EPR spectrum with $\mathrm{g}_{\perp}{ }^{\text {eff }}=$ 5.99 and $\mathrm{g}_{\|}{ }^{\text {eff }}=1.98$ resonances (Figure $3 \mathrm{~B}$, olive green trace) is characteristic of heme iron in the ferric $\left(\mathrm{Fe}^{\mathrm{III}}\right)$ high-spin (HS) state, quite distinct to that of hemin in buffer solution (Figure S5, dash-dotted gray trace) but virtually identical to that of hemin penta-coordinated to imidazole (Figure 3B, black dash-dotted trace). Hence, considering the peptide sequence (Table 1 ), we can confidently conclude a 5-c heme with His30 as axial ligand at neutral $\mathrm{pH}$, upon complexation with the GRW-L16CL30H dimer.

When raising the $\mathrm{pH}$ of the sample to 10.5 or higher, the absorption spectrum showed the total conversion to a 6-c heme (Figure $3 \mathrm{~A}$, red trace), with the characteristic redshifted Soret band (to $420 \mathrm{~nm}$ ) and the $\beta$ and $\alpha$ bands at 540 and $570 \mathrm{~nm}$, respectively. The observed split Soret band (360 $\mathrm{nm}$ and $420 \mathrm{~nm}$ ) at $\mathrm{pH} \geq 10$ (Figure $3 \mathrm{~A}$, orange and red traces) has been reported for natural proteins having a $\mathrm{Fe}^{\mathrm{III}}$ low-spin (LS) heme with thiolate ligand(s) as catalytic sites (reviewed in [22]). The new rhombic EPR signal observed for the $\mathrm{pH} 10.5$ sample (Figure $3 \mathrm{~B}$, red trace) is that of a ferric 


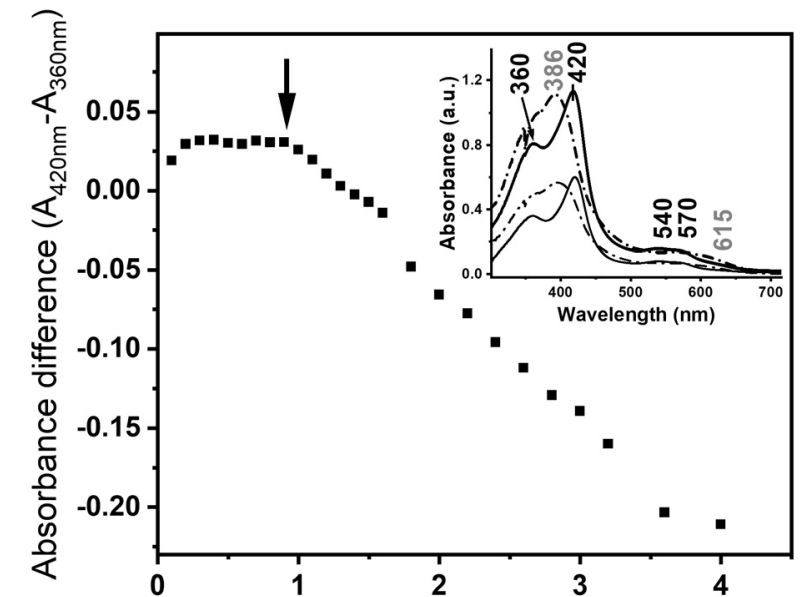

Ratio of heme to peptide dimer (molar equivalents)

Figure 2. Hemin titration into the GRW-L16CL30H $(20 \mu \mathrm{M}$ monomeric peptide concentration) in $250 \mathrm{mM}$ TRIS-maleate buffer at $\mathrm{pH}$ 10.3. The difference in absorbance of the split Soret bands $(360 \mathrm{~nm}$ and $420 \mathrm{~nm}$ ) of the GRW-L16CL3OH mini-heme protein (Inset, solid thick trace) is plotted as a function of the added hemin to peptide-dimer ratio. It clearly shows that this ratio remains constant while there is no spectral contribution of the hemin in buffer solution. Inset: The absorption spectra of the mini-heme protein obtained with 0.5 (thin solid trace) and 1 (thick solid trace) molar equivalents of heme per peptide dimer are shown. Arithmetic spectral subtractions of the "1.5 minus 1.0" (thin dashed trace) and "2.0 minus 1.0" (thick dashed trace) experimental spectra shows the expected resulting spectrum of hemin in buffer solution in both cases.

$(S=1 / 2)$ heme iron in the LS state. ${ }^{[23]}$ The g-anisotropy $(\Delta \mathrm{g}=$ $\mathrm{g}_{Z}-\mathrm{g}_{X}=0.56$ ) of such rhombic EPR spectrum (effective $\mathrm{g}$ values of $\mathrm{g}_{Z}=2.45, \mathrm{~g}_{Y}=2.25$ and $\mathrm{g}_{X}=1.89$ ) is characteristic of ferric LS heme-thiolate proteins (reviewed in [22]), thus much lower than the expected value for a ferric LS His-coordinated hemes $(\Delta g=1.6) \cdot{ }^{[23]}$ Both the absorption and the EPR spectra of the mini-heme protein at $\mathrm{pH} \geq 10.5$ are very similar to those of cyt P450 monooxygenases, having a ferric LS heme with a Cys/thiolate and water as axial ligands. ${ }^{[7]}$ Given the $\mathrm{pH}$ of the mini-heme protein, the ionized state of a water molecule should be the sixth ligand (Figure 1).

The reversible change in the GRW-L16CL30H mini-heme protein from His30 axial ligation at neutral $\mathrm{pH}$ to Cys16/ thiolate and water/hydroxide at $\mathrm{pH} \geq 10.5$, reflects a relatively weak imidazole coordination favoring heme dissociation at basic $\mathrm{pHs}$, as reported in 5 -c heme maquettes, ${ }^{[24]}$ and the concomitant deprotonation of Cys16 allowing a heme thiolate ligation. Accordingly, the main features of the absorption spectrum of GRW-L16CL30H mini-heme protein at $\mathrm{pH} 9.09$ (Figure $3 \mathrm{~A}$, blue trace), a Soret band with maximum at $397 \mathrm{~nm}$ and the broad LMCT band at ca. $625 \mathrm{~nm}$, agree well with those of a 5-c heme with a thiolate axial ligand reported in $\mathrm{CPO}{ }^{[25]}$ the HS state of cyt P450s ${ }^{[26]}$ and a $4 \alpha$-helix bundle with a Cys axial ligand to a 5-c heme $b .{ }^{[27]}$ The contribution of the LS 6-c species is indicative of a pH-dependent spin state equilibrium. Likewise, the 9-GHz EPR spectra (Figure 3B) at $\mathrm{pH} 9.14$ (blue trace) and 9.70 (orange trace) showed a new HS axial EPR signal (broad $g_{\perp}$ resonance) similar to that of hemin in cysteine buffer (Figure S5, dashed gray trace),
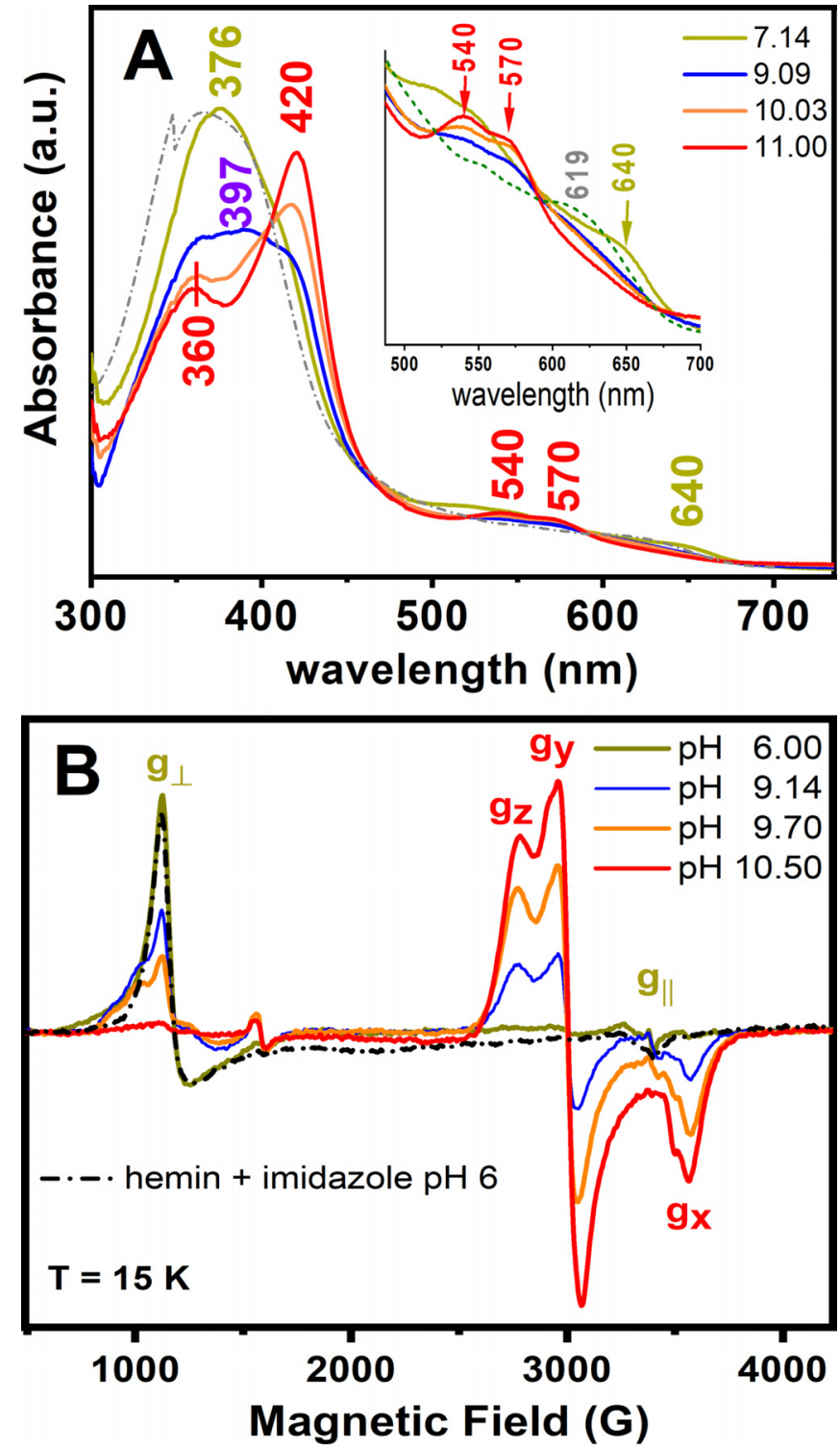

Figure 3. UV/Vis electronic absorption (Panel A) and 9-GHz EPR (Panel B) spectra of the GRW-L16CL30H mini-heme protein (15 $\mu \mathrm{M}$ and $300 \mu \mathrm{M}$ heme concentration, respectively; one heme per peptide dimer). The absorption spectrum of hemin in buffer solution $(\mathrm{pH} 7$, dash-dotted trace) and the EPR spectrum of hemin in imidazole buffer ( $\mathrm{pH} 6$, dash-dotted trace) are also shown. The $\mathrm{pH}$-induced spectral changes were fully reversible. Freezing and thawing the EPR sample did not affect the ligation and the reversibility in heme ligation. EPR experimental conditions as in Figure S6.

together with the LS-heme EPR signal observed at $\mathrm{pH} 10.5$. The relative intensities of these two EPR signals for $\mathrm{pH} \geq 9.0$ were inversely proportional. These observations are best explained by heme being mostly 5 -c to Cys 16 at $\mathrm{pH} \leq 9.5$, and converting to a 6-c (with an $\mathrm{OH}$ trans to Cys16) at higher $\mathrm{pHs}$. Similar spin state conversion and equilibrium of HS/LS species were reported for cyt $\mathrm{P} 450$ enzymes in vivo ${ }^{[28]}$ and in vitro. ${ }^{[25]}$

The $\mathrm{pH}$-dependent heme ligation pattern of the ferric mini-heme protein proved to be conserved upon reduction to the ferrous state (Figure S7). In addition, the anaerobic 
reduction/re-oxidation cycle showed that the initial heme ligation is conserved for both His- and Cys-coordinated heme (Figure S7). In cyt P450 and CPO enzymes, the thiolate axial ligand is crucial to exert the "push" effect on the heme iron during the catalytic reaction. ${ }^{[29]}$ Cyclic voltammetry (CV) studies of the cyt $\mathrm{P} 450$ heme domain showed the catalytic reduction of $\mathrm{O}_{2}$, a crucial step prior to the substrate oxygenation reaction in the catalytic cycle (Figure S1). Significantly, our CV studies on the GRW-L16CL30H mini-heme protein at $\mathrm{pH} 10.1$ also proved that it can catalyze $\mathrm{O}_{2}$ reduction (Figure 4).

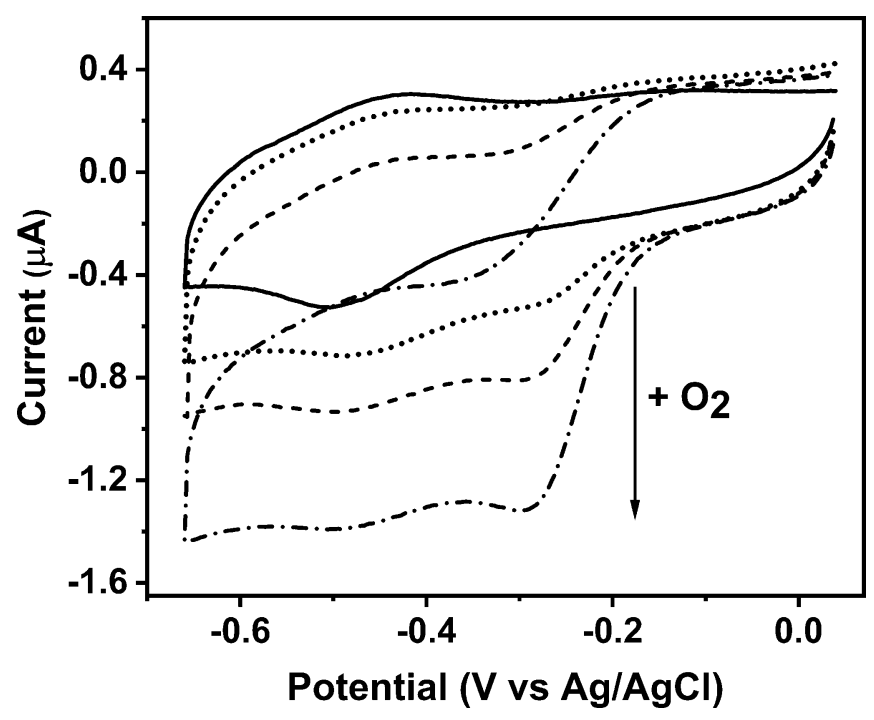

Figure 4. Cyclic voltammograms of the GRW-L16CL30H mini-heme protein ( $48 \mu \mathrm{M}$ heme and $144 \mu \mathrm{M}$ monomeric peptide concentrations) in $250 \mathrm{mM}$ TRIS-maleate buffer at $\mathrm{pH} 10.1$, entrapped in a thin layer at a pyrolytic graphite electrode, $20 \mathrm{mVs}^{-1}$ scan rate. In strict anaerobic conditions, the well-defined redox peaks revealed a redox potential

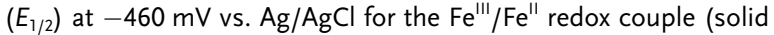
trace). In the presence of $\mathrm{O}_{2}$, the amplitude of the additional cathodic wave, with no anodic counterpart (dotted trace), was proportional to the increase in $\mathrm{O}_{2}$ concentrations (see arrow), reflecting the catalytic reduction of dioxygen by the mini-heme protein. Experimental conditions as in Figure S8.

We also characterized the GRAND scaffolds with single heme binding sites (Table 1). At $\mathrm{pH} 10.5$, the UV/Vis absorption and EPR spectra of the GRW-L16C mini-heme protein (Figure S9) were virtually identical to those of GRWL16CL30H (Figure 3). Moreover, the EPR spectra of GRWL16C mini-heme protein at pH 7.0 (Figure S9B) ruled out a 5c heme with a Cys ligand ${ }^{[30]}$ or hemin in buffer solution. Thus, at pH 7.0 and in the absence of coordinating amino acid, hydrophobic/non-covalent interactions accommodate the heme in the GRW-L16C scaffold. An equivalent situation was reported for $2 \alpha$-helix bundle maquettes. ${ }^{[24]}$ All in all, the GRW-L16C scaffold validates the coordination pattern concluded for the GRW-L16CL30H mini-heme protein at basic $\mathrm{pHs}$ and the prerequisite of Cys16 deprotonation at $\mathrm{pH} \geq 9.0$ to allow heme ligation.

The EPR spectra of the GRW-L30H mini-heme protein as a function of $\mathrm{pH}$ (Figure S10) showed heme binding to His30 at $6.50 \leq \mathrm{pH} \leq 8.50$ and dissociating otherwise, most possibly due to a longer heme $\mathrm{Fe}^{\mathrm{III}}$ to $\mathrm{N}_{\mathrm{His}}$ bond length than in natural peroxidases (see Figure S7). This confirms the heme coordination behavior observed for GRW-L16CL30H mini-heme protein at neutral $\mathrm{pHs}$, and irrespectively of the presence of a competing binding site. The GRW-L16C (at pH 10.5) and the GRW-L30H (at $\mathrm{pH}$ 7.0) mini-heme proteins showed stability upon their redox cycles (Figure S11) as well as catalytic oxidation of ABTS substrate in solution, when using $\mathrm{H}_{2} \mathrm{O}_{2}$ as oxidant (Figure $\mathrm{S} 12$ ).

In summary, we have established that a simple $\alpha$-helical scaffold design opens exciting opportunities to explore heme enzyme chemistry. By using a short, repetitive amino acid sequence with two distinct iron binding residues (His and Cys) that folds into a dimer of antiparallel 2SCC upon heme complexation, we have developed a miniature protein with heme as redox cofactor and featuring a reversible $\mathrm{pH}$-induced switch of the heme axial ligand. The resulting penta- or hexacoordinate thiolate heme for $9 \leq \mathrm{pH} \leq 11$ and penta-coordinate imidazole heme for $6 \leq \mathrm{pH} \leq 8.5$, imitating the heme ligation in $\mathrm{CPO}$, cyt $\mathrm{P} 450 \mathrm{~s}$ and peroxidases, all in a single synthetic protein, was not previously reported. Moreover, the minimal tertiary structure ensures on-demand heme coordination being stable upon redox cycling. This is a crucial property for catalysis as proved by the catalytic reduction of $\mathrm{O}_{2}$ by the GRW-L16CL30H and GRW-L16C mini-heme proteins at $\mathrm{pH} \geq 9.0$, adsorbed onto a pyrolytic graphite electrode. Further reactivity studies in solution are in progress to evaluate the extent of this very promising observation to develop versatile synthetic mini-heme catalysts.

\section{Acknowledgements}

This work was funded by the US NIH (ES012236) (to V.L.P), the French National Centre for Scientific Research (CNRS/ UMR 7281, Marseille), the French PACA Region (APR-EX "LIPCAT") and the CNRS Program for International Collaborations (PICS 07624) (to A.I). The French EPR Federation/TGE RENARD (IR3443) is also acknowledged for partial support (to A.I.). UltraScan software's development for AUC was funded by NIH grant GM120600 and data analysis by NSF/XSEDE allocation grant MCB070038-A13 (to B.D.). T.K. acknowledges a postdoctoral fellowship (APREX "LIPCAT") and a foreign researcher allowance from the city of Marseilles. We thank Jill Harland (University of Michigan, Ann Arbor) for her assistance in preparing AUC samples and Valerie Monnier (Aix Marseille Univ, CNRS, Centrale Marseille, FSCM, Spectropole, Marseille) for detailed analysis of the ESI-MS data.

\section{Conflict of interest}

The authors declare no conflict of interest.

Keywords: cyt P450 monooxygenase - protein design . EPR spectroscopy $\cdot$ heme enzymes $\cdot$ thiolate ligands 
[1] P.-S. Huang, S. E. Boyken, D. Baker, Nature 2016, 537, 320-327.

[2] I. Korendovych, W. DeGrado, Q. Rev. Biophys. 2020, 53, e3.

[3] F. Yu, V. M. Cangelosi, M. L. Zastrow, M. Tegoni, J. S. Plegaria, A. G. Tebo, C. S. Mocny, L. Ruckthong, H. Qayyum, V. L. Pecoraro, Chem. Rev. 2014, 114, 3495-3578.

[4] T. B. J. Pinter, K. J. Koebke, V. L. Pecoraro, Angew. Chem. Int. Ed. 2020, 59, 7678-7699; Angew. Chem. 2020, 132, 7750-7773.

[5] S. K. Chapman, S. Daft, A. W. Munro, Metal Sites in Proteins and Models, Vol. 88, Springer, Berlin, 1997, pp. 39-70.

[6] P. Nicholls, I. Fita, P. C. Loewen, Adv. Inorg. Chem. 2000, 51, $51-$ 106.

[7] T. L. Poulos, Chem. Rev. 2014, 114, 3919-3962.

[8] O. J. Njuma, E. N. Ndontsa, D. C. Goodwin, Arch. Biochem. Biophys. 2014, 544, $27-39$.

[9] A. Lombardi, F. Nastri, V. Pavone, Chem. Rev. 2001, 101, $3165-$ 3189.

[10] F. Nastri, M. Chino, O. Maglio, A. Bhagi-Damodaran, Y. Lu, A. Lombardi, Chem. Soc. Rev. 2016, 45, 5020-5054.

[11] F. Nastri, D. D'Alonzo, L. Leone, G. Zambrano, V. Pavone, A. Lombardi, Trends Biochem. Sci. 2019, 44, 1022-1040.

[12] P. K. Dasa, S. Samanta, A. B. McQuarters, N. Lehnert, A. Dey, Proc. Natl. Acad. Sci. USA 2016, 113, 6611-6616, and references therein.

[13] R. Perera, M. Sono, J. A. Sigman, T. D. Pfister, Y. Lu, J. H. Dawson, Proc. Natl. Acad. Sci. USA 2003, 100, 3641-3646.

[14] S. W. Vetter, A. C. Terentis, R. L. Osborne, J. H. Dawson, D. B. Goodin, J. Biol. Inorg. Chem. 2009, 14, 179-191.

[15] M. L. Zastrow, V. L. Pecoraro, Coord. Chem. Rev. 2013, 257, $2565-2588$

[16] G. R. Dieckmann, D. K. McRorie, J. D. Lear, K. A. Sharp, W. F. DeGrado, V. L. Pecoraro, J. Mol. Biol. 1998, 280, 897-912.

[17] B. Apostolovic, M. Danial, H.-A. Klok, Chem. Soc. Rev. 2010, 39, $3541-3575$

[18] D. Ghosh, V. L. Pecoraro, Inorg. Chem. 2004, 43, 7902-7915.
[19] K. Wagschal, B. Tripet, R. S. Hodges, J. Mol. Biol. 1999, 285, $785-803$.

[20] A. E. Tolbert, C. S. Ervin, L. Ruckthong, T. J. Paul, V. M. Jayasinghe-Arachchige, K. P. Neupane, J. A. Stuckey, R. Prabhakar, V. L. Pecoraro, Nat. Chem. 2020, 12, 405-411.

[21] V. N. Malashkevich, C. D. Higgins, S. C. Almo, J. R. Lai, J. Pept. Sci. 2015, 104, 178-185.

[22] A. T. Smith, S. Pazicni, K. A. Marvin, D. J. Stevens, K. M. Paulsen, J. N. Burstyn, Chem. Rev. 2015, 115, 2532-2558.

[23] A. F. Walker, Coord. Chem. Rev. 1999, 185-186, 471-534.

[24] C. T. Choma, J. D. Lear, M. J. Nelson, P. L. Dutton, D. E. Robertson, W. F. DeGrado, J. Am. Chem. Soc. 1994, 116, $856-$ 865.

[25] S. R. Blanke, S. A. Martinis, S. G. Sligar, L. P. Hager, J. J. Rux, J. H. Dawson, Biochemistry 1996, 35, 14537-14543.

[26] K. P. Conner, A. M. Schimpf, A. A. Cruce, K. J. McLean, A. W. Munro, D. J. Frank, M. D. Krzyaniak, P. R. Ortiz de Montellano, M. K. Bowman, W. M. Atkins, Biochemistry 2014, 53, $1428-$ 1434.

[27] C. C. Moser, M. M. Sheehan, N. M. Ennist, G. Kodali, C. Bialas, M. T. Englander, B. M. Discher, P. L. Dutton, Methods Enzymol. 2016, 580, 365-388.

[28] W. A. Johnston, D. J. B. Hunter, C. J. Noble, G. R. Hanson, J. E. Stok, M. A. Hayes, J. J. De Voss, E. M. J. Gillam, J. Biol. Chem. 2011, 286, 40750-40759.

[29] J. T. Groves, Nat. Chem. 2014, 6, 89-91.

[30] E. Schubert, N. Florin, F. Duthie, H. Henning Brewitz, T. Kühl, D. Imhof, G. Hagelueken, O. Schiemann, J. Inorg. Biochem. 2015, 148, 49-56.

Manuscript received: September 17, 2020

Revised manuscript received: November 19, 2020

Accepted manuscript online: November 20, 2020

Version of record online: December 23, 2020 